\title{
Sistem Informasi Rumah Produksi 8Production Films Berbasis Web
}

\author{
Muhammad Rezki ${ }^{1}$ \\ 1 Information System Departement, UIN Raden Fatah Palembang, Indonesia \\ Email: 1rezkim62@gmail.com
}

\begin{abstract}
Production House 8Production films is one of the production houses enganged in services that include multimedia, video shooting and photography in Palembang. The creation of this final project, entitled "Production House Information System In 8Production Films Based on Website". Because currently the production process include visual shooting and shooting, visual image editing and photos are still not well scheduled, only initiative, and no scheduling systematically. In addition, the management of internal operational information in the processing data from the order receipt is only stored in the form of .doc files and some are still handwritten, so that the same data recording and processing (double storage), and acces to information is slow. The System development method used in this research is Prototype. Based on the problem that have been analyzed through exixting business process observation methods. Then the system is designed by making UML (Unifield Modeling Languange). And using PHP as a programming language that will be used to create the website PHP has the extension of PHP Hypertext Preprocessor, a programming language that is anabled to build a dynamic website. While MySQL is an RDBMS software (or database server) that can manage databases very quickly. Thw result of this study are a web-based 8Production Films Production House Information System that makes ordering users easy and makes it easier for 8Production films staff to perform member absences, managing filming schedules and weekly agendas to be more effective, and making monthly reports of transactions at web-based 8Production films production houses.
\end{abstract}

Keywords: Production house of 8Production films, Information System Prototype

\section{PENDAHULUAN}

Menurut Laksono rumah produksi atau yang biasa disebut dengan Production House $(\mathrm{PH})$ adalah sebuah badan usaha yang mempunyai organisasi dan keahlian dalam memproduksi program-program audio dan audiovisual untuk disajikan kepada khalayak, sasarannya baik secara langsung maupun melalui broadcasting house. $\mathrm{PH}$ juga mengelola informasi gerak atau statis dimana informasi yang didapat bersumber dari manusia ataupun peristiwa yang ada (Laksono). 8Production films salah satu rumah produksi yang ada dikota 
Palembang, rumah Produksi ini bergerak dibidang pembuatan film-film pendek, videografi, fotografi dan video periklanan.

Rumah Produksi atau biasa disebut "Production House" (PH) adalah perusahaan pembuatan rekaman video dan perusahaan pembuatan rekaman audio yang kegiatan utamanya membuat rekaman acara siaran, sesuai dengan peraturan perundang-undangan yang berlaku, untuk keperluan Lembaga penyiaran. (Spectrum Indonesia, n.d) Rumah Produksi merupakan sebuah rumah produksi yang kegiatan sehari-harinya yang utama adalah memproduksi suatu program baik untuk acara televisi, film layer lebar, profil perusahaan, video clip, maupun iklan media elektronik. Yang kegiatannya dimulai dari perencanaan, shooting, editing sampai dengan pemasaran produk. (Muhzamzam, n,d)

Pada saat ini proses penyimpanan data anggota, pengarsipan semua kegiatan dan penyewaan jasa rumah produksi 8Production films Palembang data yang diperoleh masih belum terintegrasi tadi adalah pengarsipan dengan tulis tangan secara konvensional dan info penjadwalan yang hanya diketahui oleh pegawai 8Production films tetapi data belum bisa dilihat oleh konsumen. Cara ini mungkin dianggap efektif, namun kelemahannya akan menumpuknya pengarsipan dan pencatatan data ganda.

Dalam hal ini sistem informasi diperlukan untuk memenuhi kebutuhan yang mampu memberikan akses cepat terhadap suatu informasi. Terlebih pada proses manajemen transaksi pengelolaan pemesanan, mengharuskan adanya sistem yang dapat mengolah proses pencatatan pemasukan dan pengeluaran uang, sehingga semua proses transaksi tercatat secara terkomputerisasi dan dapat dipertanggungjawabkan dalam bentuk laporan yang sesuai. Berdasarkan latar belakang permasalahan yang telah dijelaskan, maka penulis tertarik untuk mengambil judul "Sistem Informasi Rumah Produksi 8Production Films berbasis Web".

\section{METODOLOGI PENELITIAN}

\subsection{Metode Penelitian}

Menurut Muharto dan Ambarita (2016:23), metode merupakan keseluruhan langkah ilmiah yang digunakan untuk menemukan solusi atas suatu masalah. Dengan langkah-langkah tersebut, siapapun yang melaksanakan penelitian dengan mengulang atau menggunakan metode penelitian yang sama untuk objek dan subjek yang sama akan memperoleh hasil yang sama pula. Metode penelitian berkenaan dengan cara mengumpulkan data yang selanjutnya data tersebut dapat mengantarkan pada pencapaian tujuan dan manfaat atau kegunaan tertentu. 
Metodologi penelitian yang digunakan dalam penelitian ini menggunakan pendekatan kualitatif atau dapat disebut dengan penelitian kualitatif. Penelitian kualitatif dapat diartikan sebagai metode penelitian yang berlandaskan pada filsafat postpositivisme atau enterpretif, digunakan untuk meneliti pada kondisi obyek yang alamiah, (sebagai lawannya adalah eksperimen) dimana peneliti sebagai instrumen kunci, teknik pengumpulan data dilakukan secara trianggulasi (gabungan), analisis data bersifat induktif/kualitatif, dan hasil penelitian kualitatif lebih menekankan makna dari pada generalisasi (Sugiyono, 2016:15).

\subsection{Waktu dan Tempat Penelitian}

1) Waktu Penelitian, Waktu pelaksanaan penelitian dan penyelesaian skripsi akan dilaksanakan dalam waktu, terhitung dari bulan Agustus hingga bulan Desember 2020.

2) Tempat Penelitian, Penelitian ini dilakukan pada Rumah Produksi 8Production Films Palembang di JI. PDAM, Bukit Lama, llir Barat I, Kota Palembang, Sumatera Selatan.

\subsection{Bahan Penelitian}

Bahan yang dibutuhkan meliputi data pelanggan, data pemesanan paket, jadwal kegiatan mingguan, bulanan dan tahunan, serta data profil Rumah Produksi 8Production Films yang meliputi visi dan misi 8Production films, sejarah 8Production films, struktur 8Production films dan pengurus 8Production films.

\subsection{Metode Pengumpulan Data}

Sebagai bahan pendukung bagi peneliti untuk mencari dan mengumpulkan data yang diperlukan dalam penelitian ini. Beberapa metode yang digunakan yaitu:

1) Wawancara, Menurut Yusuf (2014:372) Wawancara merupakan salah satu teknik yang dapat digunakan untuk mengumpulkan data penelitian. Secara sederhana dapat dikatakan bahwa wawancara (interview) adalah suatu kejadian atau proses interaksi anatara pewawancara (interviewer) dan sumber informasi atau orang yang diwawancarai (interview) melalui komunikasi langsung. Pada penelitian ini penulis melakukan wawancara untuk mencari dan mengumpulkan data transaksi pemesanan paket, agenda maupun aktivitas dengan cara melakukan komunikasi dan tanya jawab secara langsung kepada pihak 8Production Films.

2) Observasi (Pengamatan), Menurut Yusuf (2014:384), Observasi 
merupakan salah satu teknik yang dapat digunakan untuk mengetahui atau menyelidiki tingkah laku nonverbal. Pengamatan dilakukan secara langsung terhadap objek penelitian, serta mencatat hal-hal penting yang berhubungan dengan data pemesanan dan data pegawai yaitu proses yang sedang berjalan pada rumah produksi 8Production films sehingga diperoleh data yang lengkap dan akurat.

3) Studi Pustaka, Menurut Sugiyono (2013:83), studi pustaka merupakan langkah awal dalam metode pengumpulan data. Studi pustaka merupakan metode pengumpulan data yang diarahkan kepada pencarian data dan informasi melalui dokumen-dokumen, baik dokumen tertulis maupun dokumen elektronik yang dapat mendukung dalam proses penelitian. Peneliti mencari data secara langsung dari sumber-sumber lain seperti buku, jurnal dan hasil penelitian yang berkaitan.

\subsection{Metode Pengembangan Sistem}

Menurut Pressman (2012:50), Model pengembangan sistem Prototype yaitu model pengembangan perangkat lunak yang memungkinkan adanya interaksi antara pengembang sistem dengan pengguna sistem, sehingga dapat mengatasi ketidakserasian antara pengembang dan pengguna. (Pressman, 2012:50). Adapun model pengembangan Prototype digambarkan pada Gambar berikut:

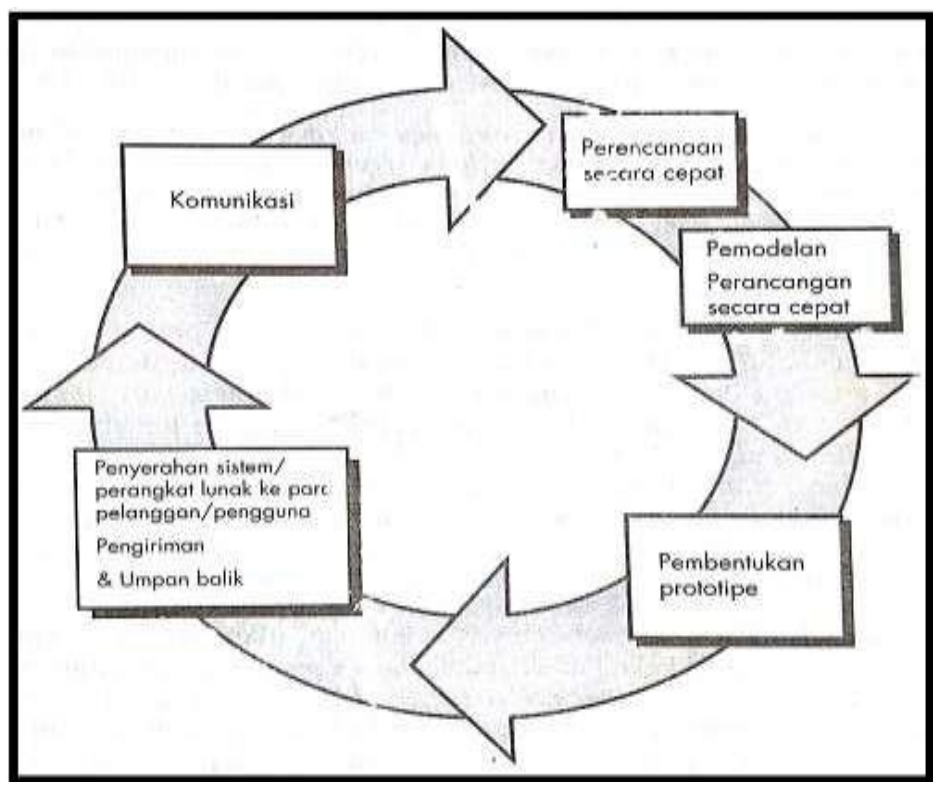

Gambar 1. Model Prototype Sumber: (Pressman,

$$
\text { 2012:51) }
$$


Model Prototype merupakan salah satu model yang mempunyai ciri khas sebagai model proses evolusioner. Model prototype dimulai dari mengumpulkan kebutuhan pengguna terhadap perangkat lunak yang akan dibuat. Prototype sendiri merupakan sesuatu yang harus dievaluasi dan dimodifikasi kembali, semua perubahan dapat terjadi pada saat prototype dibuat untuk memenuhi kebutuhan pengguna dan pada saat yang sama memungkinkan pengembangan untuk lebih memahami kebutuhan pengguna secara lebih baik (Pressman, 2012:51).

\subsection{Usecase Diagram}

Use case mendiskripsikan sebuah interaksi antara satu atau lebih actor dengan sistem informasi yang akan dibuat. Secara kasar, use case digunakan untuk mengetahui fungsi apa saja yang ada didalam sebuah sistem informasi dan siapa saja yang berhak menggunakan fungsi-fungsi itu. Berikut gambaran sistem yang akan dibangun pada gambar 2.2 dibawah ini.

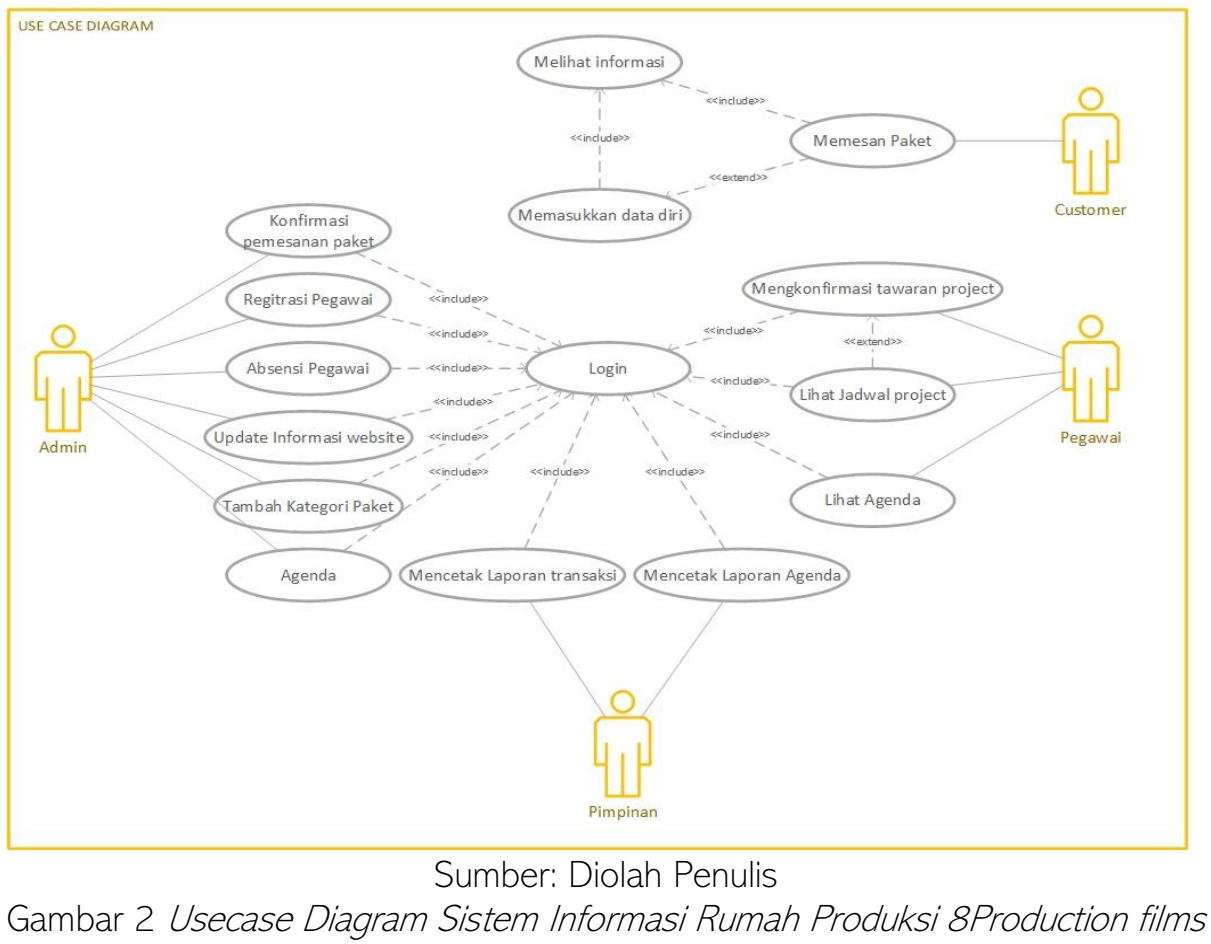


Berdasarkan Gambar 2 tersebut, Use Case Diagram diatas terdiri dari 4 aktor yaitu Admin, Pegawai, Pimpinan dan Customer. Berikut dijabarkan masingmasing identifikasi aktor tersebut pada table 2.1 dibawah ini.

Tabel 2.1 Identifikasi Aktor

\begin{tabular}{|c|c|c|}
\hline No. & Aktor & Deskripsi \\
\hline 1 & Pimpinan & $\begin{array}{l}\text { Pimpinan memliki hak akses untuk melihat } \\
\text { laporan dari seluruh transaksi dari penyewaan } \\
\text { jasa \& melihat seluruh kegiatan/Agenda yang di }\end{array}$ \\
\hline 2 & Sekretaris(Admin) & $\begin{array}{l}\text { Sekretaris(Admin) memiliki hak akses untuk } \\
\text { mengelola data pengguna, megelola data } \\
\text { anggota, melakukan registrasi menjadi anggota, } \\
\text { menginput agenda, mengkonfirmasi pemesanan, } \\
\text { melihat laboran absensi Deaawai/anaaota. } \\
\text { Pegawai(Anggota) memiliki hak akses untuk }\end{array}$ \\
\hline & & $\begin{array}{l}\text { untuk melihat jadwal project dan mengkonfirmasi } \\
\text { (menerima/menolak project) yang di berikan }\end{array}$ \\
\hline 4 & Customer & $\begin{array}{l}\text { Customer memliki hak akses untuk melakukan } \\
\text { registrasi pemesanan, melakukan pengisian data } \\
\text { diri }\end{array}$ \\
\hline
\end{tabular}

\subsection{Activity Diagram}

Activity Diagram menggambarkan proses bisnis dan urutan aktivitas dalam sebuah proses, yang biasanya dipakai pada business modeling untuk memperlihatkan urutan aktivitas bisnis. Selain bisnis, activity diagram juga dapat digunakan menggambarkan logical procedural sistem, dan aliran kerja kasus lainnya. Pembuatan activity diagram diharapkan dapat bermanfaat untuk membantu menggambarkan proses secara keseluruhan. 
Journal of Information Technology Ampera

Vol. 1, No. 1, April 2020 e-ISSN: xxxx-xxxx

https://journal-computing.org/index.php/journal-ita/index

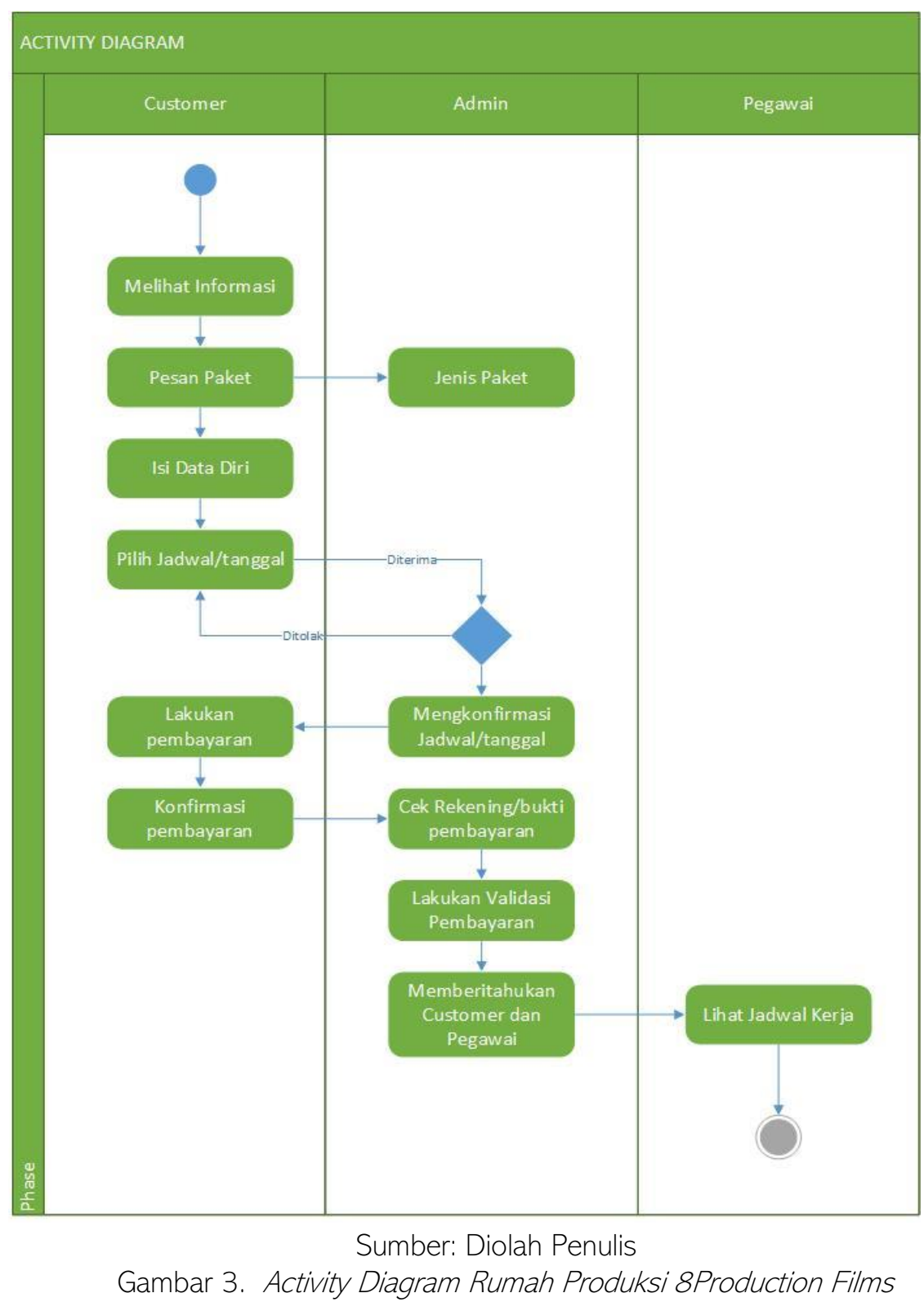

Berdasarkan Gambar 3 tersebut, maka activity diagram dari rumah produksi 8Production films dapat diuraikan berikut:

1) Customer membuka website 8Production Films untuk melihat informasi.

2) Kemudian memilih paket yang diinginkan dari berbagai jenis paket.

3) Apabila sudah memilih dan menentukan paket mana yang diinginkan 
customer mengisi data diri serta masukkan tanggal yang diinginkan.

4) Maka klik pemesanan, dan jenis paket, data diri, dan tanggal pemesanan yang diinputkan barusan akan masuk ke sistem 8Production films, dan admin akan memproses pemesanan. Jika pemesanan diterima oleh admin maka akan mendapatkan notifikasi email berupa invoice, Jika pesanan ditolak harap untuk mengganti tanggal atau masukkan data diri yang benar.

5) Kemudian customer melakukan pembayaran dan kirim bukti pembayaran.

6) Admin mengecek bukti pembayaran.

7) Admin melakukan validasi pembayaran.

8) Admin memberitahukan Jadwal kepada Customer dan memilih pegawai-pegawai yang akan bertanggung jawab atas pekerjaan tersebut.

9) Pegawai melihat jadwal dan project yang akan di kerjakan.

\subsection{Class Diagram}

Class Diagram sangat membantu dalam visualisasi struktur kelas dari suatu sistem. Gambar 2.4 menjelaskan deskripsi kelompok objek-objek dengan property perilaku (operasi) dari sistem yang akan dibangun.

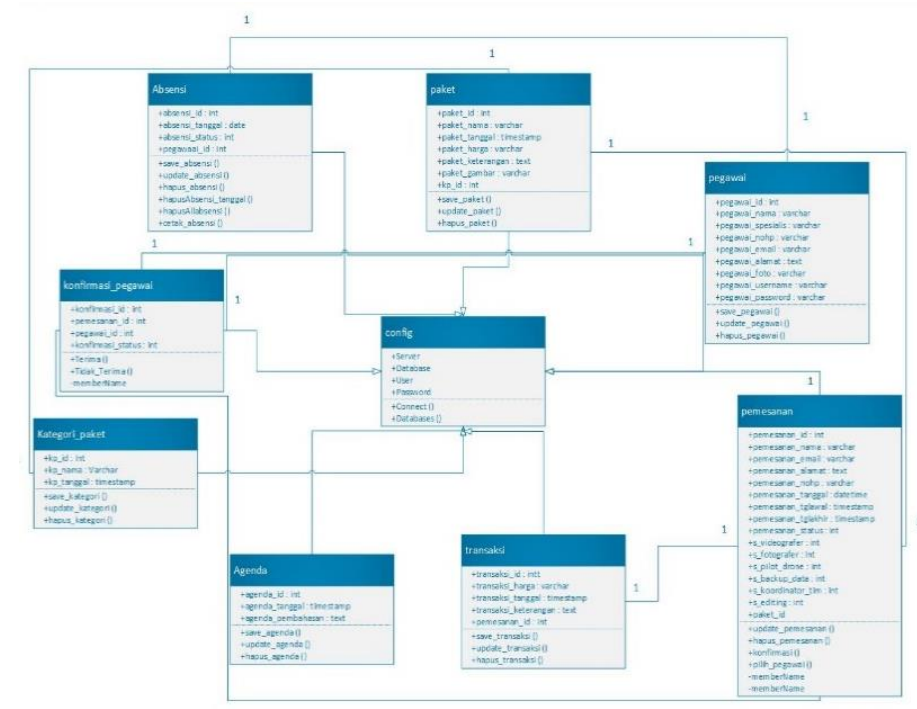

Sumber: Diolah Penulis

Gambar 2.4 Class Diagram Rumah Produksi 8Production Films 


\section{HASIL DAN PEMBAHASAN}

\subsection{Hasil}

Setelah melalui proses analisa dan perancangan sistem pada bab sebelumnya maka selanjutnya adalah bab pengkodean sistem. Setelah proses pengkodean maka dihasilkan sebuah Sistem Informasi Rumah Produksi 8Production films. Adapun proses pembuatan sistem informasi Rumah Produksi ini dibuat berdasarkan analisa dan perancangan yang sudah dilakukan sebelumnya. Pencapaian dari hasil yang didapat adalah sebagai berikut:

1) Terciptanya Sistem Informasi Rumah Produksi 8Production Films berbasis Web.

2) Pada sistem ini terdapat beberapa hak akses pengguna yaitu Admin, Pegawai dan Pimpinan.

3) Sistem ini memberikan informasi kepada Customer seputar harga dan jenis video atau foto, informasi kepada pegawai seputar pekerjaan, aktivitas mingguan, bulanan dan tahunan, memberikan informasi kepada pimpinan seputar laporan traksaksi, keuangan dan aktivitas mingguan, bulanan dan tahunan.

\subsection{Pembahasan}

Sistem ini dibangun dengan tujuan untuk menciptakan sebuah Sistem Informasi Rumah Produksi 8Production films Palembang agar dalam proses transaksi lebih mudah dan efisien. Pada sistem ini terdapat empat aktor pengguna yaitu Customer, Admin, Pegawai dan Pimpinan. Customer dapat melihat informasi seputar harga dan jenis video maupun foto setelah mengunjungi website 8Production films dan bisa melakukan pemesanan paket video maupun foto yang diinginkan. Admin memiliki hak akses login guna mengelola data pemesanan, data pegawai, absensi pegawai, agenda mingguan, bulanan dan tahunan. Pegawai memiliki hak akses login untuk melihat jadwal pekerjaan dan jadwal dari agenda mingguan, bulanan dan tahunan. Dan Pimpinan memiliki hak akses login untuk mengecek dan mencetak laporan transaksi, dan laporan dari agenda atau aktivitas mingguan, bulanan, dan tahunan

\section{KESIMPULAN}

Berdasarkan uraian dan pembahasan pada bab-bab sebelumnya, maka pada penelitian ini dapat ditarik simpulan sebagai berikut :

1) Sistem informasi rumah produksi 8Production films yang dibangun menggunakan metode pengembangan prototype dan berbasis web yang memberikan solusi untuk membantu pekerjaan di rumah produksi 
8Production films dalam proses pemesanan paket dan mengatur jadwal syuting maupun agenda-agenda yang akan dilakukan kedepannya karena dengan menggunakan metode prototype dilakukan pengecekan kembali atau evaluasi dari sistem sehingga meminimalisir tingkat kesalahan yaitu keakuratan dari sistem yang telah dibuat.

2) Sistem informasi rumah produksi membantu dalam mengelola data transaksi pemesanan paket maupun mengatur jadwal syuting dan menyajikan informasi laporan. Laporan yang dihasilkan yaitu laporan transaksi paket, pendapatan dan pengeluaran dari setiap transaksi di rumah produksi 8 Production films. Pengaruh dari sistem yang dibangun membantu penyederhanaan dalam penumpukan data yang tidak terorganisir dan dapat memberikan informasi yang cepat dan tepat.

3) Sistem informasi ini memudahkan customer untuk melakukan transaksi pemesanan paket video maupun foto secara mandiri sehingga admin hanya mengkonfirmasi pemesanan dan pengecekan transaksi dari sistem informasi rumah produksi 8 Production films tersebut.

DAFTAR PUSTAKA

Spectrum indonesia. (n.d.). Definisi Rumah Produksi. https://spectrumindonesia.com/production-house-rumah-produksi/
Muhzamzam. (n.d.).
Definisi
Rumah
Produksi.

https://elib.unikom.ac.id/files/disk1/691/jbptunikompp-gdl-

muhzamzamm-34530-8 unikom_m-i.pdf

A. Muri Yusuf. 2014. Metode Penelitian Kuantitatif, Kualitatif dan Penelitian Gabungan. Jakarta: Prenadamedia Group.

Nugrahaningsih, P., dkk. 2016. Pendampingan Pengelolaan Dana Desa Dengan Pengembangan BUMDes Berbasis Sistem Informasi Akuntansi. Surakarta: Prosiding SNA MK.

Pressman, Roger S. 2012. Rekayasa Perangkat Lunak - Buku Dua, Pendekatan Praktisi (Edisi 7). Adi Nugroho, George John Leopold Nikilujuw, Theresia Herlina Rochadiani, dan Ike Kurniawati Wijaya (Penterjemah). 2012. Yogyakarta: Andi.

Sugiyono. (2013). Metode Penelitian Kuantitatif, Kualitatif dan R\&D. Bandung: Alfabeta.

Sugiyono. (2016). Metode Penelitian Pendidikan. Bandung: Alfabeta.

King, J., Jaya, Y. T., Irfani, M. H., Mdp, S. G. I., \& No, J. R. (1978). Sistem Informasi E-Business Pada CV Valvindo Central Perkasa. X, 1-16.

Muhamad Son Muarie. (2014). Sistem Informasi Perpustakaan SMP Negeri 5 Palembang Menggunakan PHP dan MySQL. Jurnal Teknik Informatika 
Journal of Information Technology Ampera

Vol. 1, No. 1, April 2020 e-ISSN: xxxx-xxxx

https://journal-computing.org/index.php/journal-ita/index

Politeknik Sekayu (TIPS), 1(1), 24-36.

https://jurnal.polsky.ac.id/index.php/tips/article/download/64/60

Rosa AS, m. S. (2014). Rekayasa Perangkat Lunak: Terstruktur dan berorientasi objek.

King, J., Jaya, Y. T., Irfani, M. H., Mdp, S. G. I., \& No, J. R. (1978). Sistem Informasi E-Business Pada CV Valvindo Central Perkasa. x, 1-16.

Nugroho, A. (n.d.). Rekayasa Perangkat Lunak Menggunakan UML dan Java Adi Nugroho - Google Buku. Retrieved November 23, 2020

Ekosari, D. W. (2013). Sistem Informasi Persewaan Alat Pesta Berbasis Web pada CV. Tri Manunggal di Ungaran. Sistem Informasi, 13. 